\title{
Knowledge of Tooth Avulsion and its Management among Clinical Dental Students and Interns
}

\section{Brenda Ighoteguono Mohammed ${ }^{1 *}$ and Joan Emien Enabulele ${ }^{2}$}

${ }^{1}$ Senior Lecturer/Consultant (Paediatric Dentistry), Department of Child Oral

Health, University of Jos/Jos university Teaching Hospital, Jos, Plateau State, Nigeria

${ }^{2}$ Associate Professor/Consultant (Restorative Dentistry), Department of Restorative

Dentistry, University of Benin/University of Benin Teaching Hospital, Benin-city, Edo

State, Nigeria

*Corresponding Author: Brenda Ighoteguono Mohammed, Senior Lecturer/

Consultant (Paediatric Dentistry), Department of Child Oral Health, University of

Jos/Jos university Teaching Hospital, Jos, Plateau State, Nigeria.
Received: September 25, 2020

Published: November 21, 2020

(C) All rights are reserved by Brenda

Ighoteguono Mohammed and Joan Emien

Enabulele.

\begin{abstract}
Objective: To assess the knowledge of clinical dental students and interns in the emergency management of traumatic tooth avulsion. Materials and Method: This was a descriptive cross-sectional study of clinical dental students and interns at the University of Benin/University of Benin Teaching Hospital. A 13-item self-administered questionnaire which sought information on the demographic characteristics of the participants, knowledge of tooth avulsion, factors that influence success of replantation, storage media and current developments in storage media for storing an avulsed tooth was used. Data was analyzed using IBM SPSS 21.0.

Results: The study population consisted of house officers (56.9\%), final year dental students (24.1\%) and penultimate dental students (18.9\%). Majority (82.8\%) knew that an avulsed tooth is a tooth that has been completely dislodged from its socket in the alveolar bone. Majority of (90.4\%) of those who had received information regarding tooth avulsion knew what an avulsed tooth was $(\mathrm{p}<0.0001)$. There was increased experience with permanent tooth avulsion with increasing status of the respondents from penultimate student to house officers ( $\mathrm{p}<0.0001)$. A higher proportion $(90.9 \%)$ of the house officers compared to the final year students (28.6\%) and penultimate students (18.2\%) opined that an avulsed permanent tooth should not be replanted in its socket in all cases and this was statistically significant $(\mathrm{p}=0.002)$. Majority $(74.1 \%)$ of the respondents stated that dental treatment for an avulsed tooth be sought immediately after the traumatic incident. The most prevalent influencing factor observed was mechanical damage during avulsion and replantation (81.0\%). The most prevalent media selected was isotonic saline solution (81.0\%), followed by Hank's balanced salt solution (72.4\%) and patient's mouth/saliva (69.0\%). The most prevalent current development in storage media reported by the respondents was egg albumin (39.7\%), followed by coconut water (34.5\%).

Conclusion: There is need for improved knowledge regarding management of traumatic tooth avulsion.
\end{abstract}

Keywords: Traumatic Tooth Avulsion; Dental Students; Knowledge; Dental Interns

\section{Introduction}

Traumatic dental injuries (TDIs) constitute a common reason for emergency room visits [1,2]. Avulsion injuries, though occurring infrequently, are considered the most serious of all dental injuries $[3,4]$. Tooth avulsion is the complete displacement of the tooth out of its socket and involves the severance of nerve and blood ves- sels. It also involves the tearing of the periodontal ligaments which form the attachment apparatus of the tooth to its socket $[5,6]$.

Avulsion injuries account for about $1 \%$ - 11\% of all TDIs [7] and commonly seen in injuries involving the primary dentition more than the permanent dentition. The supporting structure, that is, the alveolar bone and periodontal ligament in primary dentition

Citation: Brenda Ighoteguono Mohammed and Joan Emien Enabulele. "Knowledge of Tooth Avulsion and its Management among Clinical Dental Students and Interns". Acta Scientific Medical Sciences 4.12 (2020): 64-73. 
is reported to be resilient and so following an injury, the tooth gets displaced rather than fractured [8].

Avulsed primary teeth are often not re-implanted because of possibility of damage to underlying succedaneous tooth [9]. An avulsed permanent tooth, however should be re-implanted where possible and urgently too. Positive outcomes following re-implantation depend on several factors. These include: tooth handling at the site of injury, time of presentation to the clinic, media in which tooth was transported, open or closed apex of avulsed tooth and the expertise of the managing dentist [3]. Unfavorable outcomes include pulpal death due to severed apical blood vessels, and subsequent pulpal necrosis, inflammatory root resorption and eventual tooth loss $[10,11]$.

Giving the importance of timeliness in the management of an avulsed tooth, several Nigerian studies have assessed the knowledge of avulsed teeth among paramedical students, hospital emergency unit staff, primary care physicians, dental surgery assistants in training, medical students and primary school teachers [12-17]. However, there is paucity of such studies among dental students, though studies of knowledge of tooth avulsion among Japanese [18], Brazilian [19,20], Sudanese [21] and Saudi Arabian [22] dental students exist. Furthermore, the need for dentists to know how to manage tooth avulsion as well as be prepared to manage it has been advocated [23]. Hence this study which aims to assess the knowledge of clinical dental students and interns in managing this emergency as they often are the first to see the patients in the clinic. In their respective communities as well, they may be called upon to assist when these emergencies arise.

\section{Materials and Methods}

This was a descriptive cross-sectional study of clinical dental students and interns at the University of Benin/University of Benin Teaching Hospital. Data for the study was obtained by means of a self-administered questionnaire. The data collection tool was a 13item questionnaire which sought information on the demographic characteristics of the participants, knowledge of tooth avulsion, factors that influence success of replantation, storage media for storing an avulsed tooth and current developments in storage media for storing an avulsed tooth. The questionnaire was developed from previous studies on knowledge of tooth avulsion [16,17] and advances in storage media for avulsed tooth [21,24-26] and subsequently adapted for this study. The questionnaire was pre-tested among 10 final year dental students who were not included in the study. This was to enable the researchers test the validity of the questionnaire that it will be able to garner the required information.

Written informed consent was obtained from all participants. All correct answers were given a score of 1 and incorrect answer a score of zero. For questions that had answers yes/no/I don't know all yes answers were awarded a score of 1 while no/I don't know responses were awarded a score of zero.

Collated data was screened for completeness and analyzed using IBM SPSS 21.0. The statistical tools employed in analysis were descriptive statistics which included frequency counts, percent and cross tabulations. Associations between categorical variables was determined using Chi square test and Fischer's exact where applicable. Results were presented as charts and tables.

\section{Results}

A total of 60 questionnaires were administered, however only 58 were returned giving a response rate of $96.7 \%$. The study population consisted of house officers (56.9\%), final year dental students $(24.1 \%)$ and penultimate dental students (18.9\%). There was male preponderance (67.2\%) with male female ratio of 1:0.49. The age of the respondents ranged from 20 to 30 years with a mean age of $25.71 \pm 2.04$ years.

Majority (82.8\%) knew that an avulsed tooth is a tooth that has been completely dislodged from its socket in the alveolar bone. The other respondents reported that an avulsed tooth is a tooth that has a segment fractured $(8.6 \%)$ or a tooth that has been malposition $(1.7 \%)$ while the remaining $6.9 \%$ claimed not to know what an avulsed tooth is. Table 1 shows that there was no statistically significant association between the status of the respondents and knowledge of what an avulsed tooth is. However, majority (90.4\%) of those who had received information regarding tooth avulsion knew what an avulsed tooth is $(\mathrm{p}<0.0001)$.

More than half $(69.0 \%)$ of the respondents had seen a case where a permanent tooth was avulsed. There was increased experience with permanent tooth avulsion with increasing status of the respondents from penultimate student to house officers and this was statistically significant ( $\mathrm{p}<0.0001$ ). Similarly, $75.0 \%$ of those who had received information regarding tooth avulsion had seen a case where a permanent tooth was avulsed (Table 2). 


\begin{tabular}{|c|c|c|c|c|c|}
\hline & \multicolumn{4}{|c|}{ What is an avulsed tooth? } & \multirow[b]{2}{*}{$\begin{array}{l}\text { Total } \\
\text { n (\%) }\end{array}$} \\
\hline & $\begin{array}{l}\text { A tooth that } \\
\text { has a segment } \\
\text { fractured } \\
\text { n (\%) }\end{array}$ & $\begin{array}{c}\text { A tooth that has been completely } \\
\text { dislodged from its socket in the } \\
\text { alveolar bone } \\
\text { n (\%) }\end{array}$ & $\begin{array}{l}\text { A tooth that has been } \\
\text { malpositioned } \\
\text { n (\%) }\end{array}$ & $\begin{array}{l}\text { I don't } \\
\text { know } \\
\text { n (\%) }\end{array}$ & \\
\hline Status & & & & & $\mathrm{P}=0.081$ \\
\hline House officer & $3(9.1)$ & $30(90.9)$ & $0(0.0)$ & $0(0.0)$ & $33(100.0)$ \\
\hline Final year & $1(7.1)$ & $11(78.6)$ & $0(0.0)$ & $2(14.3)$ & $14(100.0)$ \\
\hline Penultimate year & $1(9.1)$ & $7(63.6)$ & $1(9.1)$ & $2(18.2)$ & $11(100.0)$ \\
\hline $\begin{array}{l}\text { Received information } \\
\text { on tooth avulsion }\end{array}$ & & & & & $\mathrm{P}<0.0001^{*}$ \\
\hline Yes & $5(9.0)$ & $47(90.4)$ & $0(0.0)$ & $0(0.0)$ & $52(100.0)$ \\
\hline No & $0(0.0)$ & $\mathrm{I}(16.7)$ & $1(16.7)$ & $4(66.7)$ & $6(100.0)$ \\
\hline Total & $5(8.6)$ & $48(82.8)$ & $1(1.7)$ & $4(6.9)$ & $58(100.0)$ \\
\hline
\end{tabular}

Table 1: Knowledge of what an avulsed tooth is by status and previous information on tooth avulsion by the respondents.

*Fischer's Exact.

\begin{tabular}{|l|c|c|c|}
\hline \multirow{2}{*}{} & Previous experience in management of tooth avulsion & \multirow{2}{*}{ Total } \\
\cline { 2 - 4 } & $\begin{array}{c}\text { Yes } \\
\mathbf{n}(\%)\end{array}$ & $\mathbf{n}(\%)$ \\
\hline Status & & & No \\
\hline House Officer & $28(84.8)$ & $5(15.2)$ & $33(100.0)$ \\
\hline Final year & $10(71.4)$ & $4(28.6)$ & $14(100.0)$ \\
\hline Penultimate year & $2(18.2)$ & $9(81.8)$ & $11(100.0)$ \\
\hline $\begin{array}{l}\text { Received information on } \\
\text { tooth avulsion }\end{array}$ & & & $* P=0.009$ \\
\hline Yes & $39(75.0)$ & $13(25.0)$ & $52(100.0)$ \\
\hline No & $1(16.7)$ & $5(83.3)$ & $6(100.0)$ \\
\hline Total & $40(69.0)$ & $18(31.0)$ & $58(100.0)$ \\
\hline
\end{tabular}

Table 2: Previous experience in management of an avulsed tooth by status and previous information on tooth avulsion by the respondents.

*Fischer's exact.

Less than two-thirds (62.1\%) of the respondents were of the opinion that an avulsed permanent tooth should not be replanted in its socket in all cases. Less than a quarter (22.4\%) did not know if an avulsed permanent tooth should be replanted in its socket. A few $(10.3 \%)$ of the respondent felt an avulsed permanent tooth should be replanted in its socket in all cases while 5.3\% felt an avulsed permanent tooth should never be replanted in its socket. A higher proportion (90.9\%) of the house officers compared to the final year students (28.6\%) and penultimate students (18.2\%) opined that an avulsed permanent tooth should not be replanted in its socket in all cases and this was statistically significant $(\mathrm{p}=0.002)$. Similarly, majority (69.2\%) of those who had received information regarding tooth avulsion knew that an avulsed permanent tooth should not be replanted in all cases and this was statistically significant ( $p=$ 0.001) (Table 3). 


\begin{tabular}{|c|c|c|c|c|c|}
\hline & \multicolumn{4}{|c|}{ Should an avulsed permanent tooth be replanted in its socket? } & \multirow[b]{2}{*}{$\begin{array}{l}\text { Total } \\
\text { n (\%) }\end{array}$} \\
\hline & $\begin{array}{c}\text { Yes, in all cases } \\
\text { n (\%) }\end{array}$ & $\begin{array}{c}\text { Not in all cases } \\
\text { n (\%) }\end{array}$ & $\begin{array}{l}\text { Never } \\
\text { n (\%) }\end{array}$ & $\begin{array}{c}\text { I don't know } \\
\text { n (\%) }\end{array}$ & \\
\hline Status & & & & & $* \mathrm{P}=0.002$ \\
\hline House officer & $2(6.1)$ & $30(90.9)$ & $0(0.0)$ & $1(3.0)$ & $33(100.0)$ \\
\hline Final year & $1(7.1)$ & $4(28.6)$ & $2(14.3)$ & $7(50.0)$ & $14(100.0)$ \\
\hline Penultimate year & $3(27.3)$ & $2(18.2)$ & $1(9.1)$ & $5(45.5)$ & $11(100.0)$ \\
\hline Received information on tooth avulsion & & & & & $* \mathrm{P}=0.001$ \\
\hline Yes & $6(11.5)$ & $36(69.2)$ & $2(3.8)$ & $8(15.4)$ & $52(100.0)$ \\
\hline No & $0(0.0)$ & $0(0.0)$ & $1(16.7)$ & $5(83.3)$ & $6(100.0)$ \\
\hline \multirow[t]{2}{*}{ Total } & $6(10.3)$ & $36(62.1)$ & $3(5.2)$ & $13(22.4)$ & $58(100.0)$ \\
\hline & \multicolumn{4}{|c|}{ Should an avulsed primary tooth be replanted? } & \\
\hline Status & & & & & $* \mathrm{P}=0.048$ \\
\hline House officer & $2(6.1)$ & $23(69.7)$ & $5(15.2)$ & $3(9.1)$ & $(100.0)$ \\
\hline Final year & $0(0.0)$ & $6(42.9)$ & $2(14.3)$ & $6(42.9)$ & $(100.0)$ \\
\hline Penultimate year & $2(18.2)$ & $3(27.3)$ & $2(18.2)$ & $4(36.4)$ & $(100.0)$ \\
\hline Received information on tooth avulsion & & & & & $* \mathrm{P}=0.006$ \\
\hline Yes & $4(7.7)$ & $31(59.6)$ & $9(17.3)$ & $8(15.4)$ & $52(100.0)$ \\
\hline No & $0(0.0)$ & $1(16.7)$ & $0(0.0)$ & $5(83.3)$ & $6(100.0)$ \\
\hline Total & $4(6.9)$ & $32(55.2)$ & $9(15.5)$ & $13(22.4)$ & $58(100.0)$ \\
\hline
\end{tabular}

Table 3: Replantation of avulsed teeth by status and previous information on tooth avulsion by the respondents.

*Fischer's exact.

With regards to an avulsed primary tooth, $15.5 \%$ opined that an avulsed primary tooth should never be replanted. More than half $(55.2 \%)$ were of the opinion that an avulsed primary tooth should not be replanted in all cases while $6.9 \%$ claimed it should be replanted in all cases. Less than a quarter (22.4\%) of the respondents claimed not to know if an avulsed primary tooth should be replanted. Table 3 shows that a higher proportion (69.7\%) of house officers were of the opinion that avulsed primary teeth should be not be replanted in all cases $(p=0.048)$. However, only those who had received information regarding tooth avulsion knew that an avulsed primary tooth should never be replanted and this was statistically significant $(\mathrm{p}=0.006)$.

Majority (74.1\%) of the respondents opined that dental treatment for an avulsed tooth be sought immediately after the traumatic incident. A few (1.7\%) opined that dental treatment should be sought before 24 hours lapsed after the traumatic incidents while $12.1 \%$ each felt dental treatment should be sought within a few hours after a tooth has been avulsed. Table 4 depicts a statistically significant association between the status of the respondents and urgency of seeking dental care following tooth avulsion. Majority (87.9\%) of the house officers stated that dental care should be sought immediately after an avulsion injury ( $p=0.003)$. Similarly, those who had received information on tooth avulsion also knew how urgent it is for dental treatment to be sought after an avulsion injury, with $80.8 \%$ reporting immediate presentation and $11.5 \%$ advising soon after i.e. within a few hours after the injury.

Majority $(70.7 \%)$ of the respondents recommended that an avulsed tooth which becomes dirty should be rinsed gently for a few seconds without scrubbing it under running tap water, 5.2\% recommended that it should be cleaned with a toothbrush while the remaining $24.1 \%$ had no idea of what to recommend. Table 5 shows that almost all (93.9\%) the house officers recommended cleaning an avulsed tooth that becomes dirty by rinsing gently for few seconds without scrubbing it under running tap water $(\mathrm{p}$ $<0.0001)$. Similarly, majority (75.0\%) of those who had received information regarding tooth avulsion recommended cleaning an avulsed tooth that becomes dirty by rinsing gently for few seconds without scrubbing it under running tap water $(\mathrm{p}=0.05)$. 


\begin{tabular}{|l|c|c|c|c|c|}
\hline & \multicolumn{3}{|c|}{ How soon do you think it is to seek dental treatment for an avulsed tooth? } & \\
\hline & $\begin{array}{c}\text { Immediately } \\
\mathbf{n}(\%)\end{array}$ & $\begin{array}{c}\text { Within a few hours } \\
\mathbf{n}(\%)\end{array}$ & $\begin{array}{c}\text { Before 24 hours elapse } \\
\mathbf{n}(\%)\end{array}$ & $\begin{array}{c}\text { I don't know } \\
\text { n (\%) }\end{array}$ & $\begin{array}{c}\text { Total } \\
\text { n (\%) }\end{array}$ \\
\hline Status & & & & & ${ }^{*} \mathrm{P}=0.003$ \\
\hline House officer & $29(87.9)$ & $4(12.1)$ & $0(0.0)$ & $0(0.0)$ & $33(100.0)$ \\
\hline Final year & $10(71.4)$ & $1(7.1)$ & $0(0.0)$ & $3(21.4)$ & $14(100.0)$ \\
\hline Penultimate year & $4(36.4)$ & $4(36.4)$ & $1(9.1)$ & $4(36.4)$ & $11(100.0)$ \\
\hline $\begin{array}{l}\text { Received information on } \\
\text { tooth avulsion }\end{array}$ & & & & & $* \mathrm{P}=0.001$ \\
\hline Yes & $42(80.8)$ & $6(11.5)$ & $1(1.9)$ & $3(5.8)$ & $52(100.0)$ \\
\hline No & $1(16.7)$ & $1(16.7)$ & $0(0.0)$ & $4(66.7)$ & $6(100.0)$ \\
\hline Total & $43(74.1)$ & $7(12.1)$ & $1(1.7)$ & $7(12.1)$ & $58(100.0)$ \\
\hline
\end{tabular}

Table 4: Urgency of seeking dental care after tooth avulsion by status and previous information on tooth avulsion by the respondents.

*Fischer's exact.

\begin{tabular}{|c|c|c|c|c|}
\hline & \multicolumn{3}{|c|}{ If you found the avulsed tooth and it is dirty, what would you recommend? } & \multirow[b]{2}{*}{$\begin{array}{l}\text { Total } \\
\text { n (\%) }\end{array}$} \\
\hline & $\begin{array}{c}\text { Wipe the tooth } \\
\text { with a tissue paper } \\
\text { n (\%) }\end{array}$ & $\begin{array}{c}\text { Rinse gently for few seconds without } \\
\text { scrubbing it under running water } \\
\text { n (\%) }\end{array}$ & $\begin{array}{l}\text { I don't know } \\
\text { n (\%) }\end{array}$ & \\
\hline Status & & & & $* \mathrm{P}<0.0001$ \\
\hline House officer & $1(3.0)$ & $31(93.9)$ & $1(3.0)$ & $33(100.0)$ \\
\hline Final year & $1(7.1)$ & $4(28.6)$ & $9(64.3)$ & $14(100.0)$ \\
\hline Penultimate year & $1(9.1)$ & $6(54.5)$ & $4(36.4)$ & $11(100.0)$ \\
\hline $\begin{array}{l}\text { Received information on } \\
\text { tooth avulsion }\end{array}$ & & & & $* \mathrm{P}=0.05$ \\
\hline Yes & $3(5.8)$ & $39(75.0)$ & $10(19.2)$ & $52(100.0)$ \\
\hline No & $0(0.0)$ & $2(33.3)$ & $4(66.7)$ & $6(100.0)$ \\
\hline \multirow[t]{3}{*}{ Total } & $3(5.2)$ & $41(70.7)$ & $14(24.1)$ & $58(100.0)$ \\
\hline & \multicolumn{3}{|c|}{ Where do you hold the tooth while washing it? } & \\
\hline & $\begin{array}{c}\text { Crown only } \\
\text { n (\%) }\end{array}$ & $\begin{array}{c}\text { Any of Crown or root } \\
\text { n (\%) }\end{array}$ & $\begin{array}{c}\text { I don't know } \\
\text { n (\%) }\end{array}$ & $\begin{array}{l}\text { Total } \\
\text { n (\%) }\end{array}$ \\
\hline Status & & & & $* \mathrm{P}<0.0001$ \\
\hline House officer & $30(90.0)$ & $0(0.0)$ & $3(9.1)$ & $33(100.0)$ \\
\hline Final year & $5(35.7)$ & $0(0.0)$ & $9(64.3)$ & $14(100.0)$ \\
\hline Penultimate year & $2(18.2)$ & $2(18.2)$ & $7(63.6)$ & $11(100.0)$ \\
\hline $\begin{array}{l}\text { Received information on } \\
\text { tooth avulsion }\end{array}$ & & & & $* \mathrm{P}=0.017$ \\
\hline Yes & $36(69.2)$ & $1(1.9)$ & $15(28.8)$ & $52(100.0)$ \\
\hline No & $1(16.7)$ & $1(16.7)$ & $4(66.7)$ & $6(100.0)$ \\
\hline Total & $37(63.8)$ & $2(3.4)$ & $19(32.8)$ & $58(100.0)$ \\
\hline
\end{tabular}

Table 5: Handling of avulsed teeth that becomes dirty by status and previous information on tooth avulsion by the respondents.

*Fischer's exact. 
The respondents were requested to state the part of the tooth that should be held while it is being washed. Crown only was recommended by $63.8 \%$ of the respondents, either crown or root by $3.4 \%$ and $32.8 \%$ claimed not to know the part to hold. Table 5 further shows that there was statistically significant association between the status of the respondents and the part of the tooth that should be held while it is being washed if the avulsed tooth gets dirty, with $90.0 \%$ of house officers recommending the tooth be by the crown only ( $p<0.00001)$. While $59.2 \%$ of those who had received information regarding tooth avulsion stated that avulsed tooth be held by the crown only $(p=0.017)$.

With regards to how soon an avulsed permanent tooth should be replanted, $34.5 \%$ of the respondents stated that this should be done within 20 minutes after avulsion, $46.6 \%$ opined it should be done between 20 to 60 minutes, $6.9 \%$ claimed that it can be done at any convenient time while $12.1 \%$ had no idea of how soon an avulsed tooth should be replanted. A higher proportion of those who had received information regarding tooth avulsion opined that an avulsed tooth be replanted within 60 minutes of the injury $(p=0.003)$.

Varying responses were given as to the time it becomes impossible to replant an avulsed tooth: $36.2 \%$ claimed one hour after avulsion, $12.1 \%$ specified two hours after avulsion, 3.4\% reported six hours after avulsion, 29.3\% stated one day after avulsion and 19.0 had no idea.

Various factors were believed to influence the success of replantation as depicted in figure 1 . The most prevalent influencing factor observed was mechanical damage during avulsion and replantation (81.0\%). This was followed by width and length of the root canal (77.6\%) and extra-alveolar duration (74.1\%). Majority of those who had received information regarding tooth avulsion were of the opinion that extra-alveolar duration and mechanical damage during avulsion and replantation can influence success of replantation ( $p=0.017 ; 0.028)$.

Various conventional media were documented by the respondents as depicted in figure 2. The most prevalent media selected was isotonic saline solution (81.0\%), followed by Hank's balanced salt solution (72.4\%) and patient's mouth/saliva (69.0\%). The least media nominated was tissue paper/cotton wool (13.8\%), tap water $(24.1 \%)$ and antiseptic solution (27.6\%).

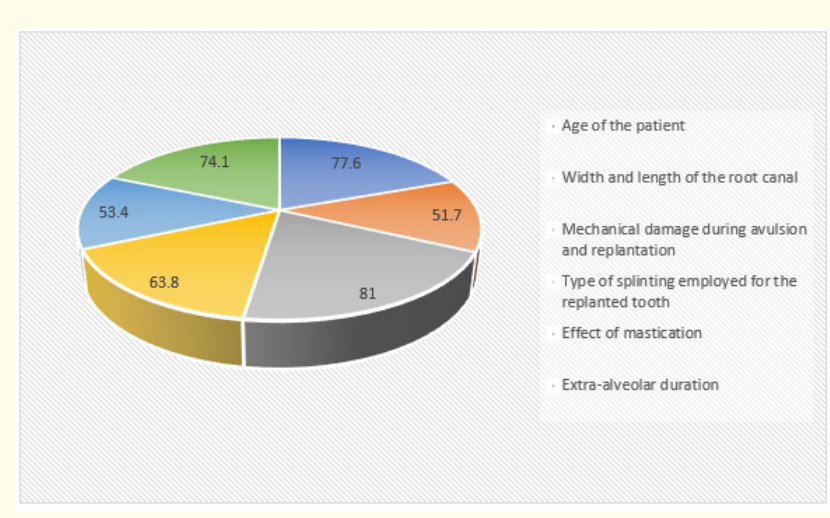

Figure 1: Factors influencing success of replantation by the respondents.

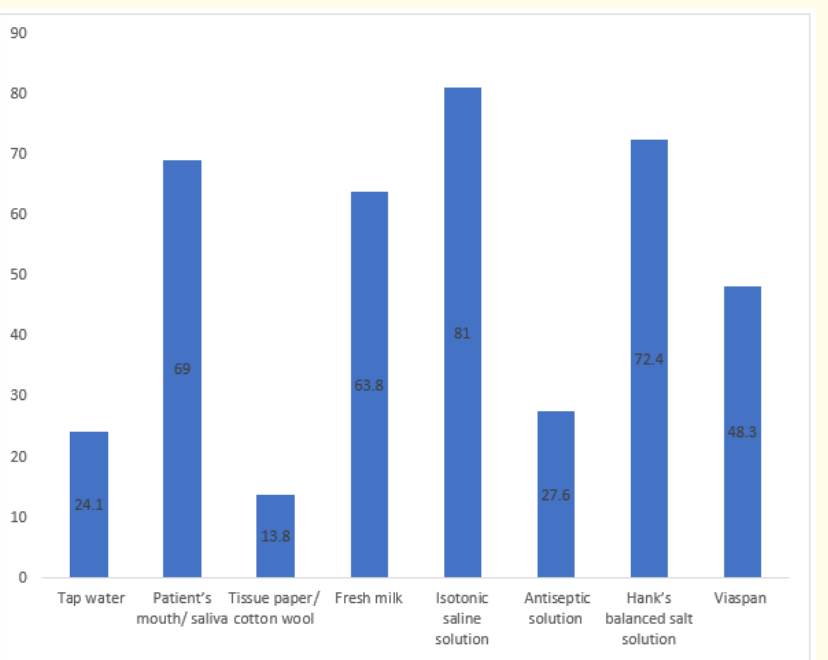

Figure 2: Conventional storage media by the respondents.

The best storage medium for avulsed teeth was stated to be Hank's balanced solution by $32.8 \%$ of the study population. About a quarter $(25.9 \%)$ had no idea of the best storage medium for avulsed teeth, $19.0 \%$ reported patient's saliva/mouth, $15.5 \%$ listed isotonic saline solution, $3.4 \%$ felt it was fresh milk while $1.7 \%$ each recorded tissue paper/cotton wool and antiseptic solution.

Current developments in storage media as enumerated by the respondents is presented in figure 3 . The most prevalent current development in storage media reported by the respondents was egg albumin (39.7\%), followed by coconut water (34.5\%), propolis and Saliva officinalis accounting for $32.8 \%$ each. The least docu- 
mented current development by the respondents were Soy milk and $\alpha$-MEM-S (supplemented with foetal calf serum and antibiotic each accounting for $17.2 \%$, followed by tooth rescue box and Morus rubra each accounting for $19.0 \%$.

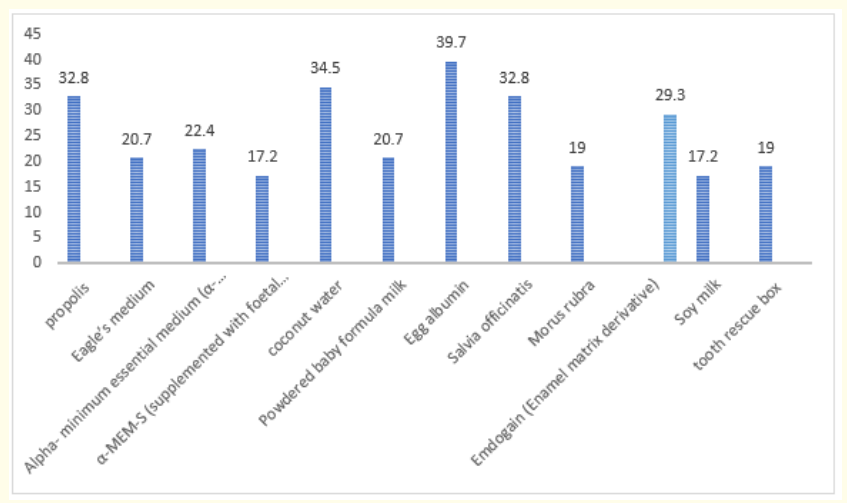

Figure 3: Current developments in storage media by the respondents.

Majority (89.7\%) claimed to have received information about tooth avulsion with $62.1 \%$ stating that they received information from lectures and clinical posting, 15.5\% from journals and textbooks, $8.6 \%$ from the internet, electronic and print media and the remaining $3.4 \%$ from friends and colleagues. However, $62.1 \%$ of the respondents still felt they were not adequately informed about managing tooth avulsion.

\section{Discussion}

This study provided baseline information on the knowledge and management of tooth avulsion injuries among final and penultimate year Dental students and recently graduated (interns) Dentists in Benin-city, in the Southern part of Nigeria. Dental trauma is part of the undergraduate curriculum in pediatric dentistry and endodontics at the University of Benin where this study was carried out.

A response of $96.7 \%$ recorded in this study is similar to that reported in previous studies $[20,22]$ and far higher than $64 \%$ reported in a Japanese study [18]. A male preponderance was observed in this study a finding similar to a Japanese report [18] but contrary to that reported in Sudan [21] and Brazil [20] who reported female predominance among dental students. This shows that undergrad- uate dental admission request is still predominantly male. The age of the respondents in this study falls within reported age range for dental students $[18,21]$.

A large proportion had received information regarding tooth avulsion. This is in keeping with previous studies [18,20]. This is because the curriculum at these levels of study includes both theoretical and clinical exposure to dental trauma.

Majority of the respondents knew an avulsed tooth to be a tooth that has been completely dislodged from its socket in the alveolar bone. A finding which corresponds with a previous report among final year dental students [21]. Knowledge of what constitutes an avulsed tooth was noted to be associated with previous exposure to information regarding tooth avulsion. This shows that receiving adequate information makes one more knowledgeable.

The proportion of respondents who had been exposed to dental trauma cases (69.0\%) was far higher than 16.2\% [18], 20.0\% [27] and 40\% [20] reported in previous studies. Experience and exposure to cases with dental trauma increased with increasing status of the respondents from penultimate student to house officers. This can be ascribed to the increase in clinical hours as one progresses from one level to another.

Those who had received had received information regarding tooth avulsion and also had exposure to clinical cases knew that an avulsed permanent tooth should not be replanted in all cases. This suggests that theoretical knowledge is not sufficient for adequate knowledge there is need for clinical exposure.

The International Association of Dental Traumatology (IADT) guidelines recommend that immediate re-implantation of an avulsed permanent tooth be done but not in all cases. Re-implantation is not recommended in severe caries, periodontal disease, non-cooperative patient, unconscious patient and patients with severe underlying medical conditions (cardiac diseases or immunosuppression) [3]. Hence, more than half of the respondents reported that an avulsed permanent tooth should not be re-implanted immediately in all cases.

Majority of the house officers opined that an avulsed permanent tooth should not be replanted in its socket in all cases. This finding differs from that done among interns in a study in Nepal, where majority of interns opined that avulsed permanent teeth should be 
replanted in all cases [26]. Knowledge of immediate re-implantation was significantly associated with status of respondents with majority of interns and final year students reporting positively which concurs with a previous report [22].

More than half of the respondents reported that an avulsed primary tooth should never be re-implanted while over a quarter of respondents did not know what to do. IADT guidelines state that an avulsed primary tooth should never be re-implanted due to likely damage to developing permanent tooth [3].

Majority of the respondents opined that treatment for an avulsed tooth be sought immediately after the incident, again, this was positively correlated with increase in status of respondents. However, a few reported that treatment be sought some hours after the injury. A previous study observed that majority of dental students felt the best time for seeking treatment is 30 minutes after the incident [21]. IADT guidelines states that treatment after an avulsion injury be instituted as soon as possible to ensure viability of the periodontal ligament cells. Periodontal ligament cells are most viable if re-implantation is done immediately or after a very short time even if kept in a suitable medium [3].

When an avulsed tooth falls it becomes dirty, there is need to address this before implantation of the tooth. This was expressed by majority of the respondents in this study by their recommendation that an avulsed tooth which becomes dirty should be rinsed gently for a few seconds without scrubbing it under running tap water. This recommendation is similar to that made in a previous study in Japan [18]. Most of the house officers and those who had received information regarding tooth avulsion made this recommendation. This illustrates that increased clinical and theoretical exposure tends to improve knowledge.

With regards to the handling of the tooth while being washed, more than half of the respondents correctly knew how to handle an avulsed tooth that becomes dirty. This is comparable to a previous study [18]. The IADT guidelines, recommend that the tooth be held by the crown while it is being washed [3]. It seems that the house officers are conversant with the IADT guidelines as almost all of them recommended that a tooth be held by the crown only while being washed.

Immediate replantation within 20 to 60 minutes of the avulsion injury was recommended by majority in this study a finding similar to a previous study [22]. IADT guidelines on avulsion injuries state that positive outcomes of these injuries are dependent on time of re-implantation of an avulsed permanent tooth, if feasible, should be within 15 minutes of injury. However, if re-implantation not immediately feasible, the tooth should be kept in an appropriate media and brought along to the clinic within one hour of injury. Avulsed primary teeth should never be re-implanted [3].

Various factors were believed to influence the success of replantation with majority stating that mechanical damage and long extra-alveolar times influence success of re-implantation. A previous study also reported time to be an important factor in predicting prognosis [21]. Prognosis of tooth has been said to become very poor with extra-oral time greater than 60 minutes [3].

IADT recommends immediate re-implantation where possible, or tooth stored in appropriate media if immediate re-implantation not possible [3]. Various conventional media that can be used to transport an avulsed tooth were documented by the respondents. The most commonly picked transport media was isotonic saline solution, followed by Hank's balanced salt solution and patient's mouth/saliva. This varies from reports of previous studies where milk was observed to be the most prevalent transport media picked $[18,20]$. Hank's balanced salt solution was adjudged the best transport media however it is not readily available at the study area. The IADT guidelines recommended fresh milk or patient's mouth/saliva at the site of injury and if access to a suitable media, HBSS or isotonic saline should be used [3].

The most prevalent current development in storage media reported by the respondents was egg albumin, coconut water, propolis and saliva officinatis. Newer transport media, such as, honey milk, Saliva officinalis, Morus rubra have claimed to preserve periodontal ligament cells for 12 - 48 hours [24]. Modified Eagle's Medium (MEM), a tissue culture, have been reported to give periodontal healing if extra-oral time is up to 5 - 14 days [25]. These newer products are however, not readily available [26] and seem to be in clinical trial phases.

Although, majority of the respondents claimed to have received information about tooth avulsion, with more than half stating that they received this information from lectures and clinical postings, more than half of the respondents still felt they were not adequately informed about management of tooth avulsion injuries. 


\section{Conclusion}

Knowledge of management of avulsion injuries among the population studied was fair. Even though, majority had received lecture in the management of these type of injuries, actual application of the knowledge is poor. Interns are often the first on call in the clinics and should be adequately informed to attend to these emergencies. Consequently, continuing dental education on traumatic dental injuries will be desirable. Treatment protocols for these injuries should be developed for each center and taught to the students. They should also be placed in strategic places within the clinic environment.

\section{Acknowledgments}

The authors will want to thank the students and interns who participated in the above study. No grant was received for this study. We also declare no conflict of interest.

\section{Bibliography}

1. Andreasen FM and Daugaard-Jensen J. "Treatment of traumatic dental injuries in children". Current Opinion in Dentistry 1 (1991): 535-550.

2. Meadow D., et al. "Oral trauma in children". The Pediatric Dental Journal 6 (1984): 248-251.

3. Andersson L., et al. "International Association of Dental Traumatology guidelines for the management of traumatic dental injuries: 2. Avulsion of permanent teeth". Dental Traumatology 28 (2012): 88-96.

4. Bastone EB., et al. "Epidemiology of dental trauma: a review of the literature". The Australian Dental Journal 45 (2000): 2-9.

5. Heithersay GS. "Replantation of avulsed teeth. A review". The Australian Dental Journal 20 (1975): 63-72.

6. Pohl Y., et al. "Results after replantation of avulsed permanent teeth. II. Periodontal healing and the role of physiologic storage and anti-resorptive-regenerative therapy". Dental Traumatology 21 (2005): 93-101.

7. Trope M. "Clinical management of the avulsed tooth: present strategies and future directions". Dental Traumatology 18 (2002): 1-11.

8. Lam R. "Epidemiology and outcomes of traumatic dental injurie s: a review of the literature". The Australian Dental Journal 61 (2016): 4-20.
9. Andreasen JO., et al. "Textbook and color atlas of traumatic injuries to the teeth, 4th edition. Oxford: Blackwell Munksgaard (2007).

10. Andreasen JO and Hjorting-Hansen E. "Replantation of teeth.I. Radiographic and clinical study of 110 human teeth replanted after accidental loss". Acta Odontologica Scandinavica 24 (1966): 263-269.

11. Trope M. "Root resorption of dental and traumatic origin. Classification based on etiology". Journal Practical Periodontics and Aesthetic Dentistry 10 (1998): 515-522.

12. Enabulele JE and Omo JO. "Pre-hospital care of traumatic tooth avulsion: knowledge on and skills in selecting pre-hospital care modalities among paramedical students in Nigeria". Tanzania Dental Journal 19 (2016): 43-49.

13. Enabulele JE., et al. "Knowledge of hospital emergency unit staff about the first-aid management of traumatic tooth avulsion in a tertiary hospital in Nigeria". EC Dental Science 5 (2016): 1082-1089.

14. Enabulele JE and Enabulele 0. "Are primary care physicians equipped enough to act as first responders for tooth avulsion injuries?" Nigerian Journal of Clinical Practice 7 (2016): 23-31.

15. Enabulele JE and Mohammed BI. "Knowledge of tooth avulsion and its emergency management among dental surgery assistants in training in Nigeria". Nigerian Journal of Clinical Practice 2 (2017): 59-64.

16. Enabulele JE and Omo JO. "Knowledge and attitude of final year medical students to first aid management of traumatic tooth avulsion: a cross-sectional survey". Journal of Medicine and Biomedical Research 14 (2015): 54-63.

17. Enabulele JE and Omo JO. "Knowledge and experience of primary school teachers towards tooth avulsion and its emergency management". Nigerian Quarterly Journal of Hospital Medicine 25 (2015): 41-46.

18. Fujita Y., et al. "Knowledge of emergency management of avulsed tooth among Japanese dental students". BMC Oral Health 14 (2014): 34.

19. Habekost APZ., et al. "Knowledge of dental students of avulsed permanent teeth". Physics in Medicine and Biology 9 (2010): 97-101.

20. Reynard E., et al. "Assessment of the dentistry undergraduates' knowledge on tooth avulsion". RSBO 13 (2016): 248-254. 
21. Azmi MA and Awooda EM. "Knowledge of emergency management of avaulsed tooth among undergraduate preclinical and clinical dental students: questionnaire-based study". Journal of Dental Research and Review 3 (2016): 140-143.

22. Al-Shamiri HM., et al. "Knowledge and attitude of dental trauma among dental students in Saudi Arabia". European Journal of Dentistry 9 (2015): 518-522.

23. Marzola C. “Transplantes e reimplantes”. $2^{\text {nd }}$ edition. Sao Paulo: Pancast (1997).

24. Limbu S., et al. "Knowledge of Dental Interns towards Emergency Management of Avulsed Tooth in Dental Colleges in Nepal". Journal of Nepal Health Research Council 12.26 (2014): $1-7$.

25. Poi WR., et al. "Storage Media For Avulsed Teeth: A Literature Review". Brazilian Dental Journal 24.5 (2013): 437-445.

26. Adnan S and Khan FR. "Storage Media For Avulsed Teeth: A Review". Journal of the Pakistan Dental Association 23.2 (2014): 54-60.

27. Karapinar-Kazandag M., et al. "Evaluation of retention of dental students' trauma knowledge following a reminder lecture". Biomedical Research (2018): 29.

\section{Assets from publication with us}

- Prompt Acknowledgement after receiving the article

- Thorough Double blinded peer review

- Rapid Publication

- Issue of Publication Certificate

- High visibility of your Published work

Website: www.actascientific.com/ Submit Article: www.actascientific.com/submission.php Email us: editor@actascientific.com

Contact us: +919182824667 